\title{
Field Management of Taro Leaf Blight using Promising Germplasm
}

\author{
D. Sarkar, N.K. Adhikary* and J. Tarafdar \\ Department of Plant Pathology, Bidhan Chandra Krishi Viswavidyalaya, \\ Mohanpur - 741252, Nadia, West Bengal, India \\ *Corresponding author
}

\begin{tabular}{|c|c|}
\hline & A B S T R A C T \\
\hline $\begin{array}{l}\text { Taro leaf bight, } \\
\text { Germplasm, } \\
\text { Season. }\end{array}$ & \multirow{3}{*}{$\begin{array}{l}\text { Taro [Colocasia esculenta var. antiquorum [(L.) Schott] suffers extensively } \\
\text { throughout the growing season as fungal leaf blight, caused by } \\
\text { Phytophthora colocasiae Raciborski. The disease affects the leaves and } \\
\text { petioles of taro plants, which are spreading rapidly, and coalesce each } \\
\text { other, thus causes extensive damage of the foliage. Resistant cultivar } \\
\text { invades the pathogen by structural, rural and biochemical means. } \\
\text { However, natural selection of field resistant lines is the key for field } \\
\text { management in acquiring resistance against leaf blight of Taro. }\end{array}$} \\
\hline Article Info & \\
\hline $\begin{array}{l}\text { Accepted: } \\
\text { 12 October } 2017 \\
\text { Available Online: } \\
10 \text { December } 2017\end{array}$ & \\
\hline
\end{tabular}

\section{Introduction}

Taro [Colocasia esculenta var. antiquorum (L.) Schott] is one of the major starchy food plants originated from tropical swamps in China, India and so on. Leaf blight of taro caused by Phytophthora colocasiae Raciborski is the most destructive fungal disease of taro [Colocasia esculenta var. antiquorum (L.) Schott]. The disease affects the leaves and petioles of taro plants, resulting in extensive damage of the foliage, typical symptoms are large often coalescing to destroy large areas of leaf.

Resistant cultivar drives variety strategies for ward off the invading pathogen that include structural rural and biochemical defense mechanisms to protect themselves. Some of this defense mechanism expressed constitutively, while other may induce upon perception of the pathogen (Hammerschmidt and Schultz, 1996). The defense response of a resistant plant directly linked to signaling event leading to the specific defense response or introducing pathogens, which play a critical role in acquiring resistance (Maleck et al., 2000).

Resistant breeding is one of the important options to manage the diseases but taro propagated by vegetative method, which hinders the breeding technique for development of resistant varieties.

Natural selection of field resistant lines is main for searching the resistant factors associated with Phytophthora colocasiae. In present experiment, nine cultivars were screened against taro leaf blight. 


\section{Materials and Methods}

The present investigation was carried out at Horticulture Research Station, Mondouri, Bidhan Chandra Krishi Viswavidyalaya, W. B. during kharif cropping season of 2014. Nine taro cultivars viz., BCC-1 (Bidhan Chaitanya), BCC-22, BCC-35, BCC-38, BCC-39, BCC-47, Sonajuly, Muktakeshi (Resistant Check) and Telia (Susceptible Check) were considered for analysing the taro leaf blight progress was monitored on individual selected leaves under in vivo condition.

Taro leaf blight progress was also monitored on individual selected Colocasia leaves. Five newly unfurled leaves from selected untreated plants (control) were tagged and monitored every three days for four weeks for symptom initiation and subsequent progression of symptoms, using the syndrome scale (Horsfall and Cowling, 1978) are as below

$0=$ No disease

$1=$ Presence of lesions less than $10 \mathrm{~cm}^{2}$ of leaf area

$2=$ Presence of lesions $11-30 \mathrm{~cm}^{2}$ of leaf area

$3=$ Presence of lesions $31-60 \mathrm{~cm}^{2}$ of leaf area

$4=$ Presence of lesions $61-90 \mathrm{~cm}^{2}$ of leaf area

$5=$ Presence of lesions more than $90 \mathrm{~cm}^{2}$ up to $25 \%$ of leaf area

$6=$ Coalesce of spot more than $25 \%$ of the leaf covered

$7=$ Coalesce of spot more than $50 \%$ of the leaf covered
$8=$ Coalesce of spot more than $75 \%$ of the leaf covered

9 = Collapse of petiole accompanied by complete leaf blight

The pattern of an epidemic in terms of the number of lesion or the area of leaf covered by blight symptoms is given by a curve that shows that progress of the disease over time in a cropped area is called area' under disease progress curve. The intensity of blight was recorded on randomly and was tagged at 15 days interval from initiation of blight i.e. July to the month of September for the season. Then the AUDPC was calculated by the formula developed by Shanner and Finey (1977).

$A U D P C=\sum_{i=1}^{n} \frac{\left(X_{i+1}+X_{i}\right)}{2} \times\left(T_{(i+1)}-T_{i}\right)$

Where,

$X_{i+1}=$ Disease severity at time $t_{i+1}$

$X_{i}=$ Disease severity at time $t_{i}$

$\mathrm{n}=$ Number of observation

\section{Results and Discussion}

Taro leaf blight caused by Phytophthora colocasiae Raciborski is the most destructive fungal disease of taro. The results of the two season evaluation trials of taro cultivars predicted the differential response to Phytophthora blight infection. High incidence of blight was recorded in the susceptible check Telia.

The results presented in table 1 and plate 1 about leaf blight index of nine taro cultivars during the consecutive cropping season in 2013 and 2014 along with the meteorological data (Table 2) and area under disease progress curve (Plate 2). Disease showed a progressive 
increase in terms of PDI. Mean percent disease index (PDI) ranged from 4.36 to 20.74. A very high incidence of blight was observed in susceptible cultivar Telia compare to others, where mean Percent Disease Index (PDI) was 20.74 and area under disease progress curve (AUDPC) was 704.42. Among the nine cultivars, minimum disease incidence was recorded on Muktakeshi and BCC-1 keeping the disease at very low level where average PDI were 4.46 and 5.34 and AUDPC were 143.78 and 196.9 respectively (Fig. 1). The cultivars like BCC22, BCC-35 and Sonajuly also showed a moderate resistant to this disease and the Mean PDI were 6.42, 6.49 and 7.54 respectively and AUDPC were 176.34, 178.09 and 206.27 respectively. The cultivars like BCC-47, BCC-38, BCC-39 and showed the moderate blight infection in leaves to the disease with mean PDI of 8.48, 8.98 and 9.80 respectively and the area under disease progress curve was 236.68, 255.15 and 277.75 respectively. The intensity of disease in Telia in both the season (2013-2014) in that period was recorded highest and the PDI were 20.84 and 20.64. The low percentage disease was found in Muktakeshi with the PDI of 5.33 and 5.35 in both the cropping season (Fig. 2).

Statistical analysis of percent disease index of leaf blight of taro in consecutive seasons (2013 and 2014) of the nine cultivars showed the moderate incidence of blight and they are statistically at par with each other. In contrast, BCC-1, BCC-22, BCC-35 and Sonajuly almost at par but BCC-47, BCC-38, BCC-39 were significantly different. Muktakeshi produce relatively more symptoms and moderately high disease severity in 2014, but from pooled data (2013-2014) it was revealed that the cultivar Muktakeshi had showed lowest disease index in both season and it was statistically at par with BCC 1, BCC-22, BCC-35 and Sonajuly, but varied from cultivars like BCC-47, BCC-38, BCC-39. In contrast, BCC- 1, BCC-22, BCC-35 and Sonajuly statically at par but BCC-47, BCC38, BCC-39 were significantly different Muktakeshi as they produce relatively more symptoms and moderately high disease severity in 2014. The results on the field incidence of leaf blight in both the seasons clearly indicated that susceptible check, Telia had very high incidence of disease where PDI ranged from 20.64 to 20.84 , which indicated that high pathogen inoculum load existed in our experimental ecological area.

It was surprising to note that during our experiment that most of the cultivars of taro had very low to moderately low infection in contrast to Telia. The cultivars of taro have the evidence of low infection in both seasons that would be due to pre- or post- infection defense related factors in the resistant cultivars. The maximum disease incidence observed on Telia and minimum disease incidence was recorded on Muktakeshi and BCC-1. The disease incidence in general continued to increase day by day, which might directly be correlated with the meteorological parameters as there was a subsequent change in temperature, maximum relative humidity, minimum relative humidity and rainfall (Table 2). In this study maximum PDI was observed when the mean average temperature was $30.17^{\circ} \mathrm{C}$, maximum relative humidity $93.12 \%$, mean minimum relative humidity $79 \%$, and mean rainfall $95.43 \mathrm{~mm}$. As the Relative humidity and rainfall provided a humid condition, which in combination with a relatively high temperature that provided an ideal condition to spread and multiplication of the pathogen. The disease was thus rapidly increased in terms of PDI values. The results are also corroborated with the earlier work of Suheri and Price (2000) and Razdan et al., (2008). Severity of the blight depends on the favourable in environmental factor, availability of inoculums and stage of plant 
growth and time of disease appearance The disease incidence in general continued to increase day by day which might directly be correlated with the epidemiological parameters as there were a subsequent increase in highest relative humidity (RH I), lowest relative humidity (RH II) and rainfall (Table 3). As the relative humidity and rainfall provided a humid condition, which in combination with a relatively high temperature that provided an ideal condition to spread and multiplication of the Phytophthora colocasiae, thus the leaf bight was rapidly increased in terms of PDI values. The estimated side corm's yield of 2013 and 2014were presented in table 4 . The highest yield was recorded in BCC-1 (15.19 $\mathrm{t} \mathrm{ha}^{-1}$ ) followed by Muktakeshi (14.12 $\left.\mathrm{t} \mathrm{ha}^{-1}\right)$ during 2012. The other cultivars like BCC-35 (12.74 $\left.\mathrm{t} \mathrm{ha}^{-1}\right)$ BCC-38 (9.03 $\left.\mathrm{t} \mathrm{ha}^{-1}\right)$ BCC-22 (12.55 t $\left.\mathrm{ha}^{-1}\right)$, BCC-47 (8.17 $\left.\mathrm{t} \mathrm{ha}^{-1}\right)$, BCC 39(8.04 $\left.\mathrm{t} \mathrm{ha}^{-1}\right)$ and Sonajuly (5.79 $\left.\mathrm{t} \mathrm{ha} \mathrm{ha}^{-1}\right)$ were showing significant difference with BCC-1 and Telia had shown the lowest possible yield of $8.03 \mathrm{t} \mathrm{ha}^{-1}$. During 2014 the maximum yield was obtained in BCC-1 (15.77 $\left.\mathrm{t} \mathrm{ha}^{-1}\right)$ followed by Muktakeshi (13.79 $\mathrm{t} \mathrm{ha}^{-1}$ ) they were statistically at par. In the cultivars BCC35 (10.79 $\left.\mathrm{t} \mathrm{ha}^{-1}\right), \mathrm{BCC}-38$ (11.91t ha $\left.{ }^{-1}\right)$, BCC$22\left(11.09 \mathrm{t} \mathrm{ha}^{-1}\right), \mathrm{BCC}-47\left(10.94 \mathrm{t} \mathrm{ha}^{-1}\right)$ and Sonajuly $\left(9.74 \mathrm{t} \mathrm{ha}^{-1}\right)$ had a significant difference with Telia where yield loss was minimum $\left(7.66 \mathrm{t} \mathrm{ha}^{-1}\right)$.

Very low yield was obtained in BCC-39 (8.11 $\mathrm{t} \mathrm{ha}^{-1}$ ) which was statistically at par with Telia where lowest yield was obtained. Pooled data of both the year showed that highest mean yield was found in BCC-1 (15.48 $\left.\mathrm{t} \mathrm{ha}^{-1}\right)$ which recorded the significant low mean PDI (5.34). The lowest mean corms yield was obtained in Telia (7.85 $\mathrm{t} \mathrm{ha}^{-1}$ ) which had expressed highest PDI (20.74) highly susceptible with leaf blight.

Table.1 Percent disease index of nine cultivars against leaf blight of taro

\begin{tabular}{|c|c|c|c|c|}
\hline \multirow{2}{*}{ Name of cultivars } & \multicolumn{2}{|c|}{ Percent disease index (PDI) } & \multirow{2}{*}{$\begin{array}{c}\text { Mean PDI } \\
\text { (POOL) }\end{array}$} & \multirow[t]{2}{*}{ AUDPC } \\
\hline & 2013 & 2014 & & \\
\hline BCC-1 & $\begin{array}{c}5.33 \\
(12.52)\end{array}$ & $\begin{array}{c}5.35 \\
(13.38)\end{array}$ & $\begin{array}{c}5.34 \\
(13.36)\end{array}$ & 143.78 \\
\hline BCC-22 & $\begin{array}{c}6.57 \\
(14.06)\end{array}$ & $\begin{array}{c}6.28 \\
(14.51)\end{array}$ & $\begin{array}{c}6.42 \\
(14.68)\end{array}$ & 176.34 \\
\hline BCC-35 & $\begin{array}{c}7.90 \\
(15.57)\end{array}$ & $\begin{array}{c}7.18 \\
(15.54)\end{array}$ & $\begin{array}{c}7.54 \\
(15.93)\end{array}$ & 206.27 \\
\hline BCC-38 & $\begin{array}{c}8.89 \\
(16.86)\end{array}$ & $\begin{array}{c}9.08 \\
(17.54)\end{array}$ & $\begin{array}{c}8.98 \\
(17.44)\end{array}$ & 255.15 \\
\hline BCC-39 & $\begin{array}{c}10.01 \\
(17.90)\end{array}$ & $\begin{array}{c}9.60 \\
(18.05)\end{array}$ & $\begin{array}{c}9.80 \\
(18.25)\end{array}$ & 277.75 \\
\hline BCC-47 & $\begin{array}{c}8.39 \\
(16.15)\end{array}$ & $\begin{array}{c}8.57 \\
(17.03)\end{array}$ & $\begin{array}{c}8.48 \\
(16.93)\end{array}$ & 236.68 \\
\hline SONAJULY & $\begin{array}{c}6.50 \\
(13.96)\end{array}$ & $\begin{array}{c}6.49 \\
(14.77)\end{array}$ & $\begin{array}{c}6.49 \\
(14.76)\end{array}$ & 178.09 \\
\hline MUKTAKESHI & $\begin{array}{c}4.43 \\
(11.64)\end{array}$ & $\begin{array}{c}4.49 \\
(12.23)\end{array}$ & $\begin{array}{c}4.46 \\
(12.19)\end{array}$ & 196.9 \\
\hline TELIA & $\begin{array}{c}20.84 \\
(26.63)\end{array}$ & $\begin{array}{c}20.64 \\
(27.03)\end{array}$ & $\begin{array}{c}20.74 \\
(27.09)\end{array}$ & 704.42 \\
\hline $\operatorname{SEM}( \pm)$ & 1.45 & 1.44 & 1.45 & -- \\
\hline $\mathrm{CD}(\mathrm{P}=0.05 \%)$ & 3.35 & 3.33 & 3.34 & -- \\
\hline
\end{tabular}


Table.2 Different meteorological factors

\begin{tabular}{|c|c|c|c|c|c|c|c|c|c|c|c|c|}
\hline \multirow{2}{*}{$\begin{array}{c}\text { Duration } \\
\text { (days) }\end{array}$} & \multicolumn{3}{|c|}{ Average Temperature $\left({ }^{0} \mathrm{C}\right)$} & \multicolumn{3}{|c|}{ Maximum RH (\%) } & \multicolumn{3}{|c|}{ Minimum RH (\%) } & \multicolumn{3}{|c|}{ Rain Fall (mm) } \\
\hline & 2013 & 2014 & pooled & 2013 & 2014 & pooled & 2013 & 2014 & pooled & 2013 & 2014 & Pooled \\
\hline $\begin{array}{c}15^{\text {th }} \\
\text { May-21 } \\
\text { May }\end{array}$ & 27.15 & 33.20 & 30.17 & 89.12 & 85.70 & 87.41 & 61.55 & 46.70 & 54.12 & 66.3 & 0.60 & 33.45 \\
\hline $\begin{array}{c}22^{\text {th }} \text { May } \\
-28 \\
{ }^{\text {th }} \text { May } \\
\end{array}$ & 24.56 & 34.90 & 29.73 & 86.37 & 85.60 & 85.98 & 57.26 & 41.70 & 49.48 & 64.23 & 0.00 & 32.12 \\
\hline $\begin{array}{l}29^{\text {th }} \text { May } \\
-4^{\text {th }} \text { June }\end{array}$ & 31.23 & 31.00 & 31.11 & 90.59 & 90.80 & 90.69 & 61.5 & 70.90 & 66.20 & 70.45 & 4.70 & 37.58 \\
\hline $\begin{array}{l}5^{\text {th }} \text { June - } \\
11^{\text {th }} \text { June }\end{array}$ & 29.45 & 31.30 & 30.375 & 92.77 & 92.10 & 92.43 & 64.23 & 73.40 & 68.81 & 199.82 & 14.70 & 107.26 \\
\hline $\begin{array}{c}12^{\text {th }} \\
\text { June- } 18^{\text {th }} \\
\text { June }\end{array}$ & 30.24 & 30.10 & 30.17 & 91.44 & 94.80 & 93.12 & 59.33 & 79.00 & 69.16 & 172.55 & 18.30 & 95.43 \\
\hline
\end{tabular}

Table. 3 Correlation between PDI and different environmental factors

\begin{tabular}{|c|c|c|c|c|c|c|}
\hline & \multirow{2}{*}{ PDI } & Avg. Temp. & RH-I & \multicolumn{2}{|c|}{ RH-II } & Rain Fall \\
\hline PDI & & & & & & \\
\hline Avg. Temp. & -0.004274 & 1 & & & & \\
\hline RH-I & 0.85288 & 0.468196 & 1 & & & \\
\hline RH-II & 0.072092 & 0.554169 & 0.50451 & 1 & & \\
\hline Rain Fall & 0.571569 & 0.584355 & 0.891001 & 0.841 & & 1 \\
\hline \multicolumn{7}{|c|}{ Table.4 Yield and yield attributing factors of nine cultivars of Colocasia esculenta } \\
\hline \multirow[t]{2}{*}{ CULTIVAR } & \multicolumn{2}{|c|}{ Yields (Tons/Hectare) } & $\begin{array}{l}\text { Mean } \\
\text { Yield }\end{array}$ & \multicolumn{3}{|c|}{$\begin{array}{l}\text { Number Of } \\
\text { Side Tubers }\end{array}$} \\
\hline & 2013 & 2014 & (Pool) & 2013 & 2014 & Pool \\
\hline BCC-1 & 15.19 & 15.77 & 15.48 & 15.45 & 17.12 & 16.29 \\
\hline BCC-22 & 12.55 & 11.09 & 11.82 & 16.01 & 16.95 & 16.29 \\
\hline BCC-35 & 12.74 & 10.79 & 11.77 & 12.33 & 14.95 & 13.64 \\
\hline BCC-38 & 9.03 & 11.91 & 10.47 & 12.23 & 14.47 & 13.35 \\
\hline BCC-39 & 8.04 & 8.11 & 8.08 & 10.24 & 9.66 & 9.95 \\
\hline BCC-47 & 8.17 & 10.94 & 9.56 & 11.65 & 9.24 & 10.45 \\
\hline SONAJULY & 10.54 & 9.74 & 10.14 & 16.34 & 15.02 & 15.68 \\
\hline MUKTAKESHI & 14.12 & 13.79 & 13.96 & 21.23 & 19.73 & 20.48 \\
\hline TELIA & 8.03 & 7.66 & 7.85 & 9.26 & 8.56 & 8.91 \\
\hline $\operatorname{SEM}( \pm)$ & 0.93 & 0.85 & 0.85 & 1.25 & 1.32 & 1.24 \\
\hline $\mathrm{CD}(\mathrm{P}=0.05 \%)$ & 2.15 & 1.97 & 1.95 & 2.87 & 3.03 & 2.86 \\
\hline
\end{tabular}


Fig.1 Nine cultivars of taro tested against leaf blight

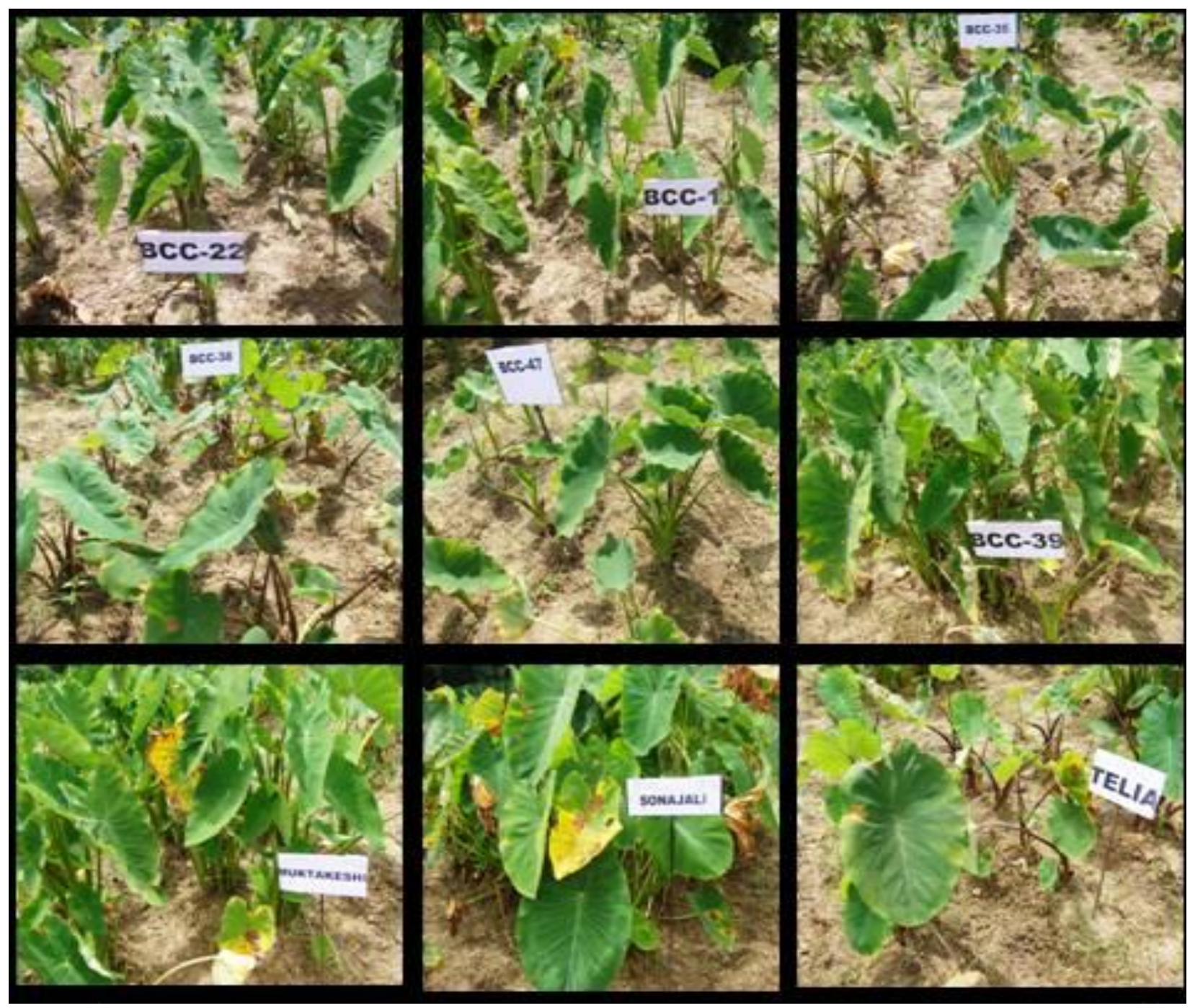

Fig.2 AUDPC of tested genotypes of Taro against leaf blight

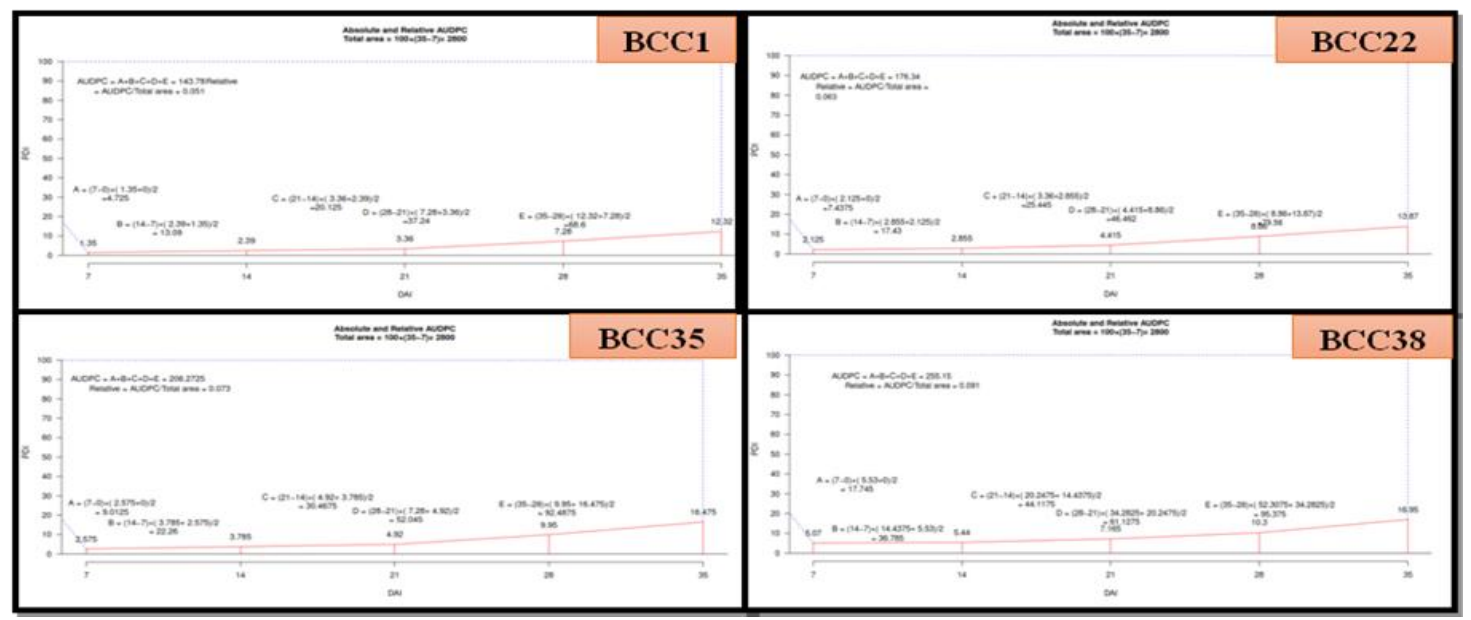




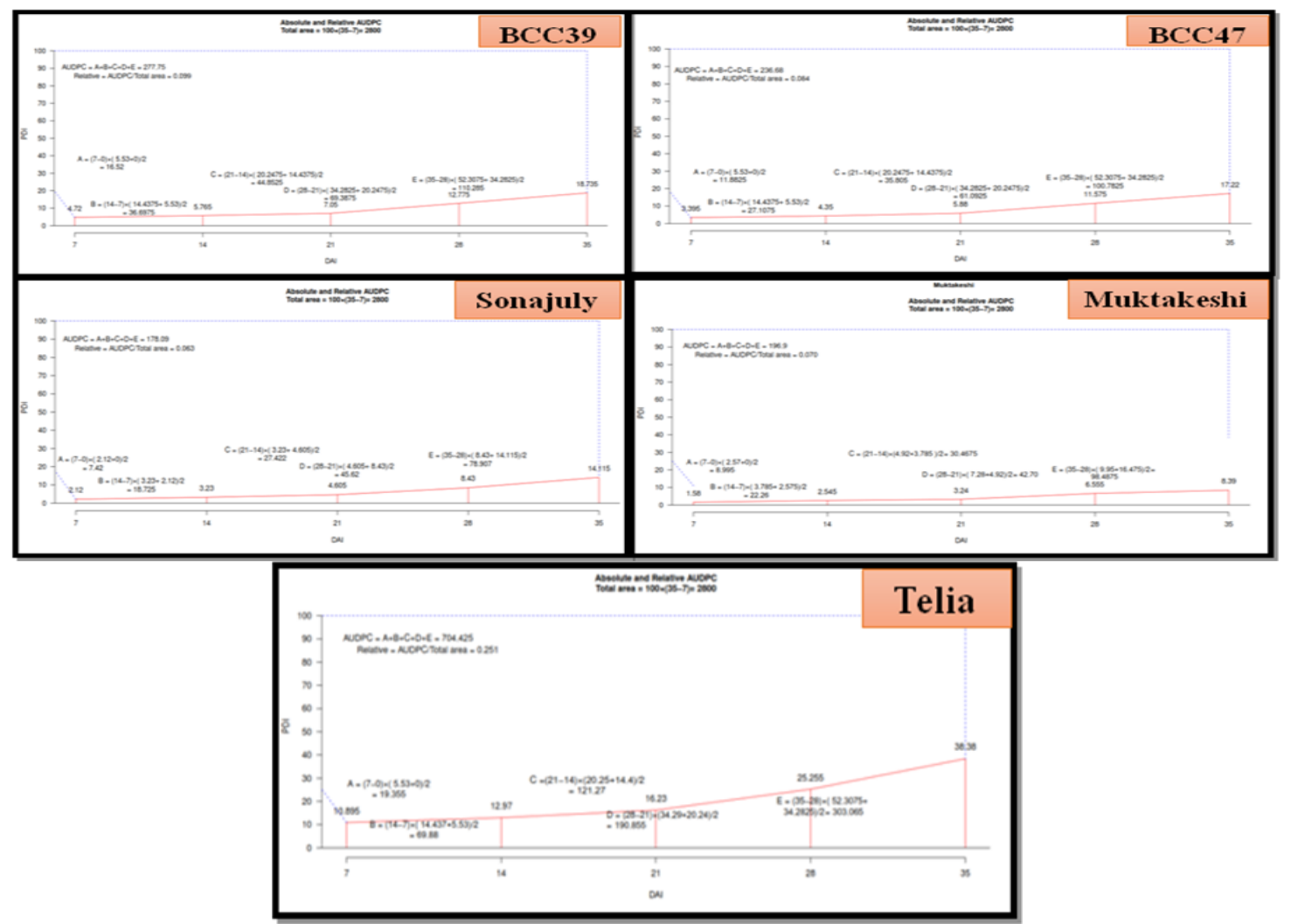

Number of side tubers per plant varies among the different cultivars. The number side tubers production was highest in Muktakeshi was 21.23 and 19.73 in 2013 and 2014 respectively. Pooled data of both year had shown high the number of side tubers were also high in BCC-1 (16.29) followed by BCC22 (16.29) and Sonajuly (15.68) where pooled PDI was 5.34 and 6.42 and 6.49 respectively. The minimum number of side tuber yield was obtained in Telia (8.91) where pooled PDI was highest 20.74. The corm yield data of the cultivars predicted that high infection of Phytophthora colocasiae had adverse effect on the side tubers formation as evidenced in the susceptible verities, Telia where blight was very high compared to others and the yield of side corm was recorded lowest among the cultivars of taro.

The analysis of leaf blight presented data showed that Muktakeshi, BCC-1, BCC-22, BCC-35 and Sonajuly were field tolerant to the disease and Telia is highly susceptible cultivar in both the season. Singh and Okpul (2000) in well supported with the earlier observation make this observation, they screened the 12 cultivars selected from 32 elite cultivars, and they found that all cultivars were resistant to leaf blight except the locally preferred cultivar. It was also supported by findings of Tarafdar et al., (2004) evaluated elite cultivars of taro during 2004 and found that BCC-16, BCC-24, BCC32 and BCC-1 had high level of resistant. These have been a continuous emphasis on crop breeding programs in improving resistance towards disease and pests through the use of resistance donor varieties. Thus the use of resistant varieties are the most simple, effective and economic means of plant disease management and accordingly numerous varieties have been bred and released as disease resistance cultivars. Sen et al., (2002) who compared the promising taro cultivars against the Phytophthora leaf blight also found similar observation and they concluded that Muktakeshi was resistant to 
this disease. They also observed that BCC-1 had very good response in term of corm yield and resistant to blight disease. Later the cultivar Muktakeshi has been released as resistance variety against the leaf blight disease (Anonymous, 2006).

Correlation between epidemiological data and average Percent disease index (PDI) showed in the table 3. Percent disease index (PDI) was positively correlated with the relative humidity and rainfall but negatively correlated with the average temperature.

These results indicate that high humidity or rainfalls are the most important predisposing factors for disease development that supported by Shakywar et al., (2012). Muktakeshi and BCC-1 are the tolerant cultivars, which showed low PDI at suitable epidemiological environment. Razdan et al., (2008) and Suheri and Price (2000) results are agreed with the earlier work.

However our present investigation lend the previous report on the incidence of blight disease and clearly indicated that the cultivars like Muktakeshi was highly resistant to blight and the promising cultivars viz., BCC 1, BCC-22, BCC-35 and Sona july have the strong genetic base for its resistant to blight disease.

Leaf blight of taro is the most devastating disease of taro and occurred most of the taro growing districts of West Bengal. This investigation suggests that Resistant or tolerant cultivar by way of natural selection based on wide field experiment is always preferable, which is also statistically justified.

The differential response to natural incidence of leaf blight among the cultivars clearly indicated that some factors would be associated with resistance and slow blighting characters of the cultivars.

\section{References}

Anonymus. 2006. Annual Report of All India Coordinated Research Project on Tuber Crops (other than potato). ICAR.

Hammerschmidt, R. and Schuttz, J.C. 1996. Multiple defense and signal in plant defense against pathogen and herbivores. Phytochemical Diversity and Redundancy in Ecological interactions, Plenum Press, New York, pp. 141.

Horsfall, J.G. and Cowling, E.B. 1978. Pathometry: The measurement of plant disease. In: Plant Disease: An Advanced Treatise. 2: How disease Develop in Populations (J.G. Horsefall and E.B. Cowling, Eds.). Academic Press, New York, pp. 119-136.

Maleck, K., Levine, A., Eulgem, T., Morgan, A., Schmid, I. Lawton, K.A., Dangl, J.L. and Dietrich, R.A. 2000. The transcriptome of Arabidopsis thaliana during systemic acquired resistance. Nature Genetics, 26: 403-410.

Razdan, V.K., Efath, S., Kumar, Sudheer. 2008. Influence of weather parameters on purple blotch of onion. Indian Phytopathol., 61(1): 90-94.

Sen, S., Das, S., Das, A.K., Pal, S., Sen, S., Das, S. and Pal, S. C. 2002. Peroxidase polyphenol oxidase, total phenol and protein contain in leaf tissue of Colocasia esculenta var. antiquorum and their relationship to Phytophthora leaf blight disease, J. Veg. Crops Prod., 8(1): 83-89.

Shakywar, R.C., Pathak, S.P., Pathak, M. and Singh, A.K. 2012. Evaluation of taro (Colocasia esculenta var. antiquorum) genotypes against leaf blight (Phytophthora colocasiae Racib.) under eastern Uttar Pradesh condition. Hort. Flora Res. Spectrum, 1(2): 184-186.

Shanner, O. and Finey, R.E. 1977. The effect of nitrogen fertilizer on the expression 
of slow mildering resistance in lenox wheat. Phytopath, 67: 1051-1056.

Singh, D. and Okpul, T. 2000. Evaluation 12 taro [Colocasia esculenta (L.) Schott] leaf blight resistant clones for yield and eating quality in Papua New Guinea. $\boldsymbol{J}$ of Breeding and Genetics, 32(1): 39-45.

Suheri, H. and Price, T.V. 2000. Infection of onion leaves by Alternaria porri and Stemphylium vesicarium disease development in controlled environments. Plant Pathology, 49: 375-382.

Tarafdar, J., Mandal, N. and Sen, H. 2004. Performance of some promising cultivars of taro [Colocasia esculenta var. antiquorum (L.) Schott] against Phytophthora leaf blight disease, yield component and variation in peroxidase isoforms. Asian J. Microbiol. Biotech. Env. Sci., 6: 25-29.

\section{How to cite this article:}

Sarkar, D., N.K. Adhikary and Tarafdar, J. 2017. Field Management of Taro Leaf Blight using Promising Germplasm. Int.J.Curr.Microbiol.App.Sci. 6(12): 1399-1407. doi: https://doi.org/10.20546/ijcmas.2017.612.157 